\title{
THE ELEMENT OF TORT AS AFFECTING THE LEGAL LIABILITY OF THE UNITED STATES
}

\author{
Charles C. Binney, of the Pennsylvania Bar.
}

Under section I059 of the Revised Statutes, the general jurisdiction of the Court of Claims (i.e., its jurisdiction independent of special statutes and of the Abandoned and Captured Property Act, which was of limited duration) covered "claims founded upon any law of Congress, or upon any regulation of an Executive Department, or upon any contract, express or implied, with the Government of the United States," and also the claims of disbursing officers for relief from responsibility on account of the capture of Government funds, vouchers, etc., during the Civil War.

This court had no power to render a final judgment, appealable to the Supreme Court of the United States under the Act of March 3, 1863, until the defect in that Act, pointed out in Gordon v. United States, was removed by the Act of March I7, 1866; but after the way was clear for appeals the question of the Government's liability in cases of tort was among the first to come before the Supreme Court.

In Gibbons $v$. United States, ${ }^{2}$ the Government's officers had prevented the claimant from completing the performance of his contract to deliver oats within a certain time; but at a later date, when oats had risen in price, had demanded performance of the balance of the contract, and the claimant had seen fit to comply The suit was for the cost of the later deliveries of oats, over and above the contract price paid, as well as for two other items which were clearly due to breach of contract. It was held that the contract had been terminated by the original refusal to receive the oats when tendered, and that the claimant's subsequent consent to renew it was either voluntary or obtained by duress, which latter, if exerted, was a tort for which the officer might have been personally liable, but did not impose any liability on the Government. Miller, J., admitted the absence of direct precedent, owing to the novelty of suits against the United States, but pointed out that in suits brought by the Government its rights

22 Wall., 561 . (See opinion in 117 U. S., 697.)

28 Wall., 269. 
had been held not to be impaired by the laches of its officers, however gross. ${ }^{3}$ He further said:

"It is not to be disguised that this case is an attempt, under the assumption of an implied contract, to make the Government responsible for the unauthorized acts of its officer, those acts being in themselves torts. No government has ever held itself liable to individuals for the misfeasance, laches, or unathorized exercise of power by its officers and agents. .. .

"The language of the statutes which confer jurisdiction upon the Court of Claims, excludes by the strongest implication demands against the Government founded on torts. . . .

"In the absence of adjudged.cases determining how far the Government may be responsible on an implied assumpsit for acts which, though unauthorized, may have been done in its interest, and of which it may have received the benefit, the apparent hardships of many such cases present strong appeals to the courts to indemnify the suffering individual at the expense of the United States.

"These reflections admonish us to be cautious that we do not permit the decisions of this court to become authority for the righting, in the Court of Claims, of all wrongs done to individuals by the officers of the General Government, though they may have been committed while serving. that government, and in the belief that it was for its interest. In such cases, where it is proper for the nation to furnish a remedy, Congress has wisely reserved the matter for its own determination. It certainly has not conferred it on the. Court of Claims."

In Morgan v. United States, the Government had chartered a vessel, assuming the war risk; the owners agreeing to bear the marine risk. Against the judgment of the master and the pilot, the quartermaster in charge ordered her to be taken across a dangerous bar, and she was severely injured. It was held that the high wind and low stage of water were the proximate causes of the injury, but that even if the quartermaster's order could be regarded as the cause, there could be no recovery based on a tortious act, because "Congress has wisely reserved to itself the right to give or withhold relief where the claim is founded on the wrongful proceedings of an officer of the Government."

In Langford v. United States, the American Board of Commissioners for Foreign Missions claimed to own certain lands

U. S. v. Kirkpatrick, 9 Wheat., 720; Dox v. Postmaster General, 1 Pet., 318.

14 Wall., 531.

s 101 U. S., 341. 
and buildings which had been taken possession of by agents of the Indian Bureau. The Board had not consented to this taking, and brought. suit for use and occupation. The Supreme Court held that there was no jurisdiction over such suit, saying:

"Conceding that the title, or even the right to the possession of the premises, was in claimant, it would seem that the facts above stated show that the act of the United States in taking and holding that possession was an tnequivocal tort, if the Government can be capable of committing one, and if the case were between individuals every implication of contract would be repelled."

The appellant had contended, however, that under the maxin, Rex non potest peccare, the United States could not commit a tort, and also that under the Constitution private property could not be taken for public use without compensation; but the court held, in the first place, that even in England the maxim of the king's impeccability related to him alone, not to the Government or those who administer it, and secondly, that an implied contract to pay the just value of property taken could only arise when the fact of the private ownership was not disputed. ${ }^{8}$

"It is a very different matter where the Government claims that it is dealing with its own, and recognizes no title superior to its own. In such case the Government, or the officers who seize such property, are guilty of a tort, if it be in fact private property. No implied contract to pay can arise any more than in the case of such a transaction between individuals. It is conceded that no contract for use and occupation would, in that case, be implied. ... There can be no reasonable doubt that this limitation [of the jurisdiction of the Court of Claims] to cases of contract, express or implied, was established in reference to the distinction - between actions arising out of contracts, as distinguished from those founded on torts, which is inherent in the essential nature of judicial remedies.under all systems, and especially under the system of the common law.

The reason for this restriction is very obvious on a moment's reflection. While Congress might be willing to subject the Government to the judicial enforcement of valid contracts, which could only be valid as against the United States, when made by some officer of the Government acting under lawful authority,

It is interesting to note that the Supreme Court did not then undertake to decide whether, even when the Government "acting by the forms that are sufficient to bind it, recognizes the fact that it is taking private property for public use," a recovery could be had in the Court of Claims. The right of suit in such cases was positively upheld in $U$. S. v. Great Falls Mfg. Co., 112 U. S., 645. 
with power vested in him to make such contracts, or to do acts which implied them, the very essence of a tort is that it is an unlawful act, done in violation of the legal rights of some one. For such acts, however high the position of the officer or agent of the Government who did or cornmanded them, Congress did not intend to subject the Government to the results of a suit in that court. This policy is founded in wisdom, and is clearly expressed in the Act defining the jurisdiction of the court; and it would ill become us to fritter away the distinction between actions $e x$ delicto and actions $e x$ contractu, which is well understood in our system of jurisprudence, and thereby subject the Government to payment of damages for all the wrongs committed by its officers or agents, under a mistaken zeal, or actuated by less worthy motives."

All these cases were decided under the first statute which gave the Court of Claims jurisdiction as an actual court, and that jurisdiction was somewhat amplified by the Act of March 3, $1887^{\top}$ (commonly called the Tucker Act), being at the same time conferred concurrently, with certain limitations, upon the District and Circuit courts throughout the country. The greater part of the jurisdiction (and the only part which need now be considered) embraces what are now recognized as four distinct classes of cases, ${ }^{8}$ viz.:

(I) All claims founded upon the Constitution of the United States or any law of Congress, except for pensions, or

(2) Upon any regulation of an Executive Department, or

(3) Upon any contract, express or implied, with the Govern. ment of the United States, or

(4) For damages, liquidated or unliquidated, in cases not sounding in tort.

All these four classes are further described by the words, "in respect of which claims the party would be entitled to redress against the United States either in a court of law, equity, or admiralty, if the United States were suable."

Shortly after the jurisdiction was thus amplified a suit was brought for the principal of certain Government bonds which, it was alleged, the Register of the Treasury had cancelled, negligently and without authority of law, issuing new ones in their place to other parties than the real owners of the original bonds. It was held that the Government was not liable, the Supreme Court saying:

724 Stats., 505 ; 1 Supp. R. S., 559.

8 See Dooley r. U. S., 182 U. S., 222, 224. 
"It is a well settled rule of law that the Government is not liable for nonfeasances or misfeasances, or negligence of its officers, and that the only remedy to the injured party in such cases is by appeal to Congress. . . . If this be treated as a case of tort, then it is clear that the Government is not liable, not only upon the ground above stated, but because under the Act of Congress conferring jurisdiction upon the Court of Claims, 24 Stat., 505, c. 359, there is an express exception of cases sounding in tort."

This doctrine was more recently recognized by Brown, J., in his concurring opinion in United States v. Lynah (188 U. S., 445,479 ), in which, while differing from the rest of the court on some points, he said:

"I freely admit that, if the property were seized or taken by officers of the Government without authority of law, or subsequent ratification, by taking possession or occupying property for public use, there could be no recovery, since neither the Government nor any other principal is bound by the unauthorized acts of its agents."

These repeated statements of the doctrine make it perfectly clear that under the present jurisdiction of the courts, the Government cannot be held liable on a claim which exists solely by reason of a tort committed by a Government officer, even in the course of his performance of official duty, but there remains the broader question of whether the Government can be sued in cases founded upon the Constitution, of an Act of Congress, or a regulation of an Executive Department, where any element of tort enters into the case. In dealing with this question the cases must be studied very closely, and all dicta carefully separated from the actual grounds of decision.

United States $v$. Jones ${ }^{2}$ involved merely the question of whether a-federal court could compel the issue of a patent for public land, not a matter of tort at all, but the opinion contains this statement in regard to the Tucker Act:

"The jurisdiction here given to the Court of Claims is precisely the same as that given in the Acts of 1855 and 1863 , with the addition that it is extended to 'damages . . . in cases not sounding in tort' and to claims for which redress may be had 'either in a court of law, equity or admiralty." "

The statement above quoted is clearly inaccurate, as it makes no mention of claims founded upon the Constitution, and it must be regarded as a dictum except in so far as it bears upon the precise question before the court.

- 131 U. S., 1, 16. 
Hill v. United States ${ }^{10}$ involved only the question of whether the Government could be sued for use and occupation of real estate when it pleaded a paramount title. The Supreme Court held that if the plaintiff's title was good, the case was one of tort, and hence governed by Langford $v$. United States, already cited, but Gray, J., went beyond this, and undertook to generalize in regard to the Tucker Act, saying:

"The whole effect of the Act of March 3, 1887, c. 359, under which this suit was brought, was to give the Circuit and District courts of the United States jurisdiction, concurrently with the Court of Claims, of suits to recover damages against the United States, in cases not sounding in tort. United States $v$. Jones, 131 U. S., $1,16,18$.

The United States cannot be sued in their own courts without their consent, and have never permitted themselves to be sued in any court for torts committed in their name by their officers. Nor can the settled distinction, in this respect, between contract and tort, be evaded by framing the claim as upon an implied contract. Gibbons v. United States, 8 Wall., 269, 274; Langford $v$. United States, IOI U. S., 34I, 346; United States v. Jones, above cited."

The dictum as to "the whole effect" of the Tucker Act was simply a more emphatic than accurate way of saying that the Act gave no jurisdiction to try questions of title to real estate as between the Government and other parties, in suits for use and occupation. The sweeping statement as to torts, however, goes beyond what, was needed to decide the issue in that case, and the references to the Gibbons and Langford cases show that the learned judge had in mind only cases of tort pure and simple and did not consider the subject of tortious violations of constitutional or statutory rights.

Schillinger $v$. United Statcs ${ }^{11}$ was a claim for the wrongful use of a patented invention in the construction of a certain pavement, or, in other words, for infringement of the patent, an unquestionable tort. The opinion cites the provisions of the Acts of 1863 and 1887 , defining the jurisdiction of the Court of Claims, and says:

"Under neither of these statutes had or has the Court of Claims any jurisdiction of claims against the Government for mere torts; some element of contractual liability must lie at the foundation of every action."

10149 U. S., 593, 598.

11155 U. S., 163. 
The opinion goes on to cite the passages from Gibbors $v$. $U$. S. and Morgan v. U. S., already quoted above, adding:

"The rule thus laid down has been consistently followed by this court, in many cases up to and including the recent case of Hill v. Urited States, 149 U. S., 593, 598.

If there was any error in this interpretation first announced in 1868, of the scope of the Act, and if it was the intent of Congress to grant to the court jurisdiction over actions against the Government for torts, an amending statute of but a few words would have corrected the error and removed all doubt. While the language of the Act of 1887 is broader than that of 1855 , it is equally clear in withholding such jurisdiction. It added, "all claims founded upon the Constitution of the United States," but that does not include claims founded upon torts, any more than "all claims founded upon any law of Congress" found in the prior Act. The identity of the descriptive words excludes the thought of any change.

It is said that the Constitution forbids the taking of private property for public uses without just compensation; that therefore every appropriation of private property by any official to the uses of the Government, no matter how wrongfully made, creates a claim founded upon the Constitution of the United States and within the letter of the grant in the Act of 1887 of the jurisdiction to the Court of Claims. If that argument be good, it is equal$1 y$ good applied to every other provision of the Constitution as well as to every law of Congress. This prohibition of the taking of private property for public use without compensation is no more sacred than that other constitutional provision that no person shall be deprived of life, liberty, or property, without due process of law. Can it be that Congress intended that every wrongful arrest and detention of an individual, or seizure of his property by an officer of the Government, should expose it to an action for damages in the Court of Claims? If any such breadth of jurisdiction was contemplated, language which had already been given a restrictive meaning would have been carefully avoided.

It is true also that to jurisdiction over claims founded "upon any contract, expressed or implied, with the Government of the United States," is added jurisdiction over claims "for damages, liquidated or unliquidated," but this grant is limited by the provision "in cases not sounding in tort." This limitation, even if qualifying only the clause immediately preceding, and not extending to the entire grant of jurisdiction found in the section, is a clear endorsement of the frequent ruling of this court that cases sounding in tort are not recognizable in the Court of Claims."

The last sentence of the above extract scarcely shows the late Mr. Justice Brewer's usual lucid reasoning. If the words, "in 
cases not sounding in tort," did not extend to the entire grant of jurisdiction, then the jurisdiction over claims founded upon the Constitution or a law of Congress or a Departmental regulatior must cover all such claims, whether "sounding in tort" -or not. there being nothing irreconcilable between the condition of being founded upon the Constitution or a statute, and the condition of "sounding in tort." If a claim "sounding in tort" has nothing else to support it than the mere tort, then it may be said to be founded on a tort; but if its foundation is upon the Constitution a law of Congress, or a Departmental regulation, that foundatior cannot be destroyed by the mere fact that the act which violatec the claimant's constitutional or other rights was itself of a tortious character. It is therefore not surprising that the sweeping statements of the opinion were strongly dissented from by Harlan and Shiras, J. J., who said:

"There is another view of the case which is independent of mere contract. The Act of March 3, 1887, for the first time, gives thi Court of Claims jurisdiction to hear and determine "all claim. founded upon the Constitution of the United States." If the Schillinger patent be valid, and if the invention described in $i^{4}$ has been used or appropriated by the Government through it agent charged with the improvement of the Capitol grounds, the the patentee or those entitled to enjoy the exclusive rights grante by it, are entitled to be compensated by the Government. An. the claim to have just compensation for such an appropriation o. private property to the public use is "founded upon the Constitr tion of the United States." It is none the less a claim of that char acter, even if the appropriation had its origin in tort. The con stitutional obligation cannot be evaded by showing that the orig. inal appropriation was without the express direction of the Gov. ernment, nor by simply interposing a denial of the title of thr. claimant to the property or property rights alleged to have bees appropriated. The questions of title and appropriations are for judicial determination. Those being decided in favor of the claimant, the Constitution requires a judgment in his favor. If the claim here made to be compensated for the use of a patented invention, is not founded upon the Constitution of the United States, it would be difficult to imagine one that would be of that character."

In United States $v$. Berdan Fire Arms $\mathrm{Co}^{12}$ the suit was for the use of two patented inventions, and the Supreme Court held that a contract must be implied as regards the later patent, though not as regards the earlier one. The opinion states:

12156 U. S., 552. 
"With respect to the first, little need be said. . . E Even if there were findings sufficient to show that the Government had in any manner infringed upon this patent, there is nothing disclosing a contract, express or implied, and a mere infringement, which is. only a tort, creates no cause of action cognizable in the Court of Claims. Gibbons v. United States, 8 Wall., 269; Morgan v. United States, 14 Wall., 53I ; Hill v. United States, I49 U. S., 593 ; Schillinger v. United States, I55 U. S., 163. . . .

But as heretofore stated, something more than a mere infringement, which is a tort and not within the jurisdiction of the Court of Claims, is necessary to enable the petitioner to maintain this action. Some contractual liability must be shown."

In that case no attempt seems to have been made to base the claim on the patentee's constitutional or statutory rights, but suit was brought solely upon the theory of an implied contract, which failed as to the first patent, though it was sustained as to the second one. Assuming that the first patent had been used, which was not clearly proved, the only alternative presented was that between tort and contract, and hence the court cannot be critcised, as in the Schillinger case, for failing to recognize the constitutional basis of the claim. At the same time the court's desire to give the claimant all the relief possible led it to take a very advanced positon in implying a contract as to the second patent, holding that, in the absence of any denial of the patentee's title, the expressed willingness of the Government's officers that the patentee should sue in the Court of Claims, was equivalent to a contract to pay whatever rate of royalty the court should find to be due. It is obvious that in a suit.between individuals such a development of the doctrine of implied contracts would never have been resorted to, and the case would have been one of tort; and one can only conclude that while "the settled distinction between tort and contract" (to quote Judge Gray's words in Hill $z$. United States) is recognized in suits against the United States, as well as in other litigation, the distinction is not quite the same in the one class of cases as in the other.

In Russell $v$. United States ${ }^{13}$ suit was brought for the alleged use of a patented invention, on the theory of an implied contract, but the facts alleged in the petition showed infringement only, and it was held that no contract could be implied. McKenna, $J$., said:

"It is conceded that a contract must be established to entitle appellants to recover, and, it is contended, that one is established by

18182 U. S., 516. 
the correspondence between the Ordnance Department and Russell in regard to the use of the "Army rifle," which, it is claimed, contained features of Russell's invention. That is, not an express contract is claimed, but an implied contract is claimed. This court has held that under the Act of March 3, I887, 24 Stat., 505, c. 359, defining claims of which the Court of Clains had jurisdiction, the court had no jurisdiction of demands against the United States founded on torts. Schillinger $v$. United States, I55 U. S., 163; United States v. Berdan Fire Arms Co., 156 U. S., 552. In other words, to give the Court of Claims jurisdiction, the demand sued on must be founded on a convention between the parties"a coming together of minds." . .

If the United States was a person, on the facts of this record (assuming, of course, the petition to be true) it could be sued as upon an implied contract, but it is the prerogative of a sovereign not to be sued at all without its consent or upon such causes of action as it chooses. It has not chosen to be sued in an action sounding in tort, this court has declared, as we have seen."

The expression, "If the United States was a person ... . it could be sued as upon an implied contract," must mean "it could be sued in tort as well as upon an implied contract," which is undoubtedly true; whereas, in that particular case the only reason why the United States could not be sued as upon an implied contract would have been as applicable in the case of an ordinary person, viz., that no contract could fairly be implied from the facts. On those facts a person might have been sued for the tort of infringement, but the Government could not be sued at ali.

The statement in the paragraph first quoted, that "to give the Court of Claims jurisdiction, the demand sued on must be founderl on . . . 'a coming together of minds' "' is equally elliptical, for though worded as a broad generality, it only applies to cases of contract, not to claims founded on the Constitution or an Act of Congress, where the facts can hardly be regarded as involving "a coming together of minds." In short, all that this case really decides is that when the petition alleges facts showing a tort and nothing more-a case "founded on tort"- -there can be no recovery on the ground of a contract, and the general language of the opinion must fairly be understood with reference to the narrow scope of the decision.

Harlan, J., who had dissented in the Schillinger case, did not participate in the Russell case. Had he done so, he would almost certainly have joined in the dissent of Shiras, White and Peckham, J. J. It seems clear, however, that not all the five judges who formed the majority in the Russcll case intended to 
maintain any such proposition as that the Government could not be sued for any cause of action involving a tort, for on the very same day four ${ }^{\text {It }}$ out of the five joined with Harlan, J., in a decision which announced a more liberal rule. This case (Dooley $v$. United States) ${ }^{16}$ was one of the celebrated "Insular Cases," involving the constitutional status of Porto Rico. The suit was to recover duties upon imports from the United States to Porto Rico, collected first under the terms of the commanding general's proclamation, and afterwards under a customs tariff proclaimed by the President. Suit had been brought in one of the circuit courts, as a Court of Claims, and the jurisdiction was attacked. The Supreme Court's opinion referred to the four classes of cases above mentioned, saying, "The words 'not sounding in tort,' are in terms referable only to the fourth class of cases," and farther on in the same opinion Brown, J., said:

"In the cases under consideration the argument is made that the money was tortiously exacted, that the alternative of payment to the collector was a seizure and sale of the merchandise for the non-payment of duties; and that it mattered not that at common law an action for money had and received would have lain against the collector to recover them back. But whether the exactions of these duties were tortious or not; whether it was within the power of the importer to waive the tort and bring suit in the Court of Claims for money had and received, as upon an implied contract of the United States to refund the money in case it was illegally exacted, we think the case is one within the first class of cases specified in the Tucker Act of claims founded upon a law of Congress, namely, a revenue law, in respect to which class of cases the jurisdiction of the Court of Claims, under the Tucker Act, has been repeatedly sustained."

- Of course, the same reasoning would apply in the case of a claim founded upon the Constitution, but in the subsequent case of United States $v$. Lynah, ${ }^{18}$ the majority of the court failed to apply this reasoning, being unable to agree as to the ground on which their decision should be based. The suit was for the value of certain land which had been destroyed by flooding, due to the Government's erection of dams and other obstructions in the Savannal river. Five of the eight judges sitting sustained the claim, but only one of them (Brown, J.) did so exclusively on the

\footnotetext{
14 McKenna, J., who wrote the majority opinion in Russcll v. United States, was not one of the four.

18182 U. S., 222.

1018 U. S., 445.
} 
ground that the case was an ordinary one of trespass to real estate, containing no element whatever of contract, and that as the claim was founded upon the Constitution, it was wholly erroneous to say that a contract should be implied. His view (as previously intimated in Dooley v. United States) was that the words of the statute, "not sounding in tort," were meant to refer exclusively to that particular class of cases in connection with which they were used, viz., actions for damages, liquidated or unliquidated. Two others of the majority held that the land had been taken by eminent domain, so that damages could be recovered under an implied contract, while the remaining two (Shiras and Peckham JJ.) held that recovery might be had on either ground. The three dissentients held that the land had not been taken at all but merely injured, and as two of them had formed part of the majority in the Dooley case, while the third had dissented in the Russell case, it is fair to assume that if a majority of the court could have agreed that the case involved a claim founded upon the Constitution, the doctrine announced in the Dooley case would have been directly reaffirmed.

It cannot be denied that the doctrine of Dooley $v$. United States involves a broader view of the Government's liabilities than was taken in the earlier cases. This doctrine, in fact, seems to be that of the dissenting judges in the Schillinger case, rather than that of the majority. Still, it must be remembered that the petition in the Schillinger case, which was very unskillfully drawn, positively averred a wrongful use of the patented invention, made no mention of constitutional rights, and merely referred to supposed statutory rights as follows:

"Your petitioners claim the right to recover the damages done to them by this wrong, and the saving or profit made by the United States, as the basis of this suit is upon their patent rights, which are founded upon the patent laws of the United States."

In argument the appellant's counsel did, it is true, attempt to base the claim upon the constitutional right to compensation for property taken, but the findings of fact had made the tort so prominent as to prevent the majority of the Supreme Court from seeing anything but tort in the case. Had the petition rested exclusively upon the constitutional right of compensation, without stigmatizing the Government's acts as wrongful, and against the will of the claimants, the findings also would presumably have been differently worded, and another state of facts would have been presented. 
Similarly in the Russell case the petition did not attempt to found the claim upon the Constitution, the claimants apparently believing that their only hope was that a contract might be implied from the facts, under the rather advanced doctrine which, as stated above, the Supreme Court had announced in regard to one of the patents in United States v. Berdan Fire Arms Co. It was held, however, that as both parties had treated the case all along as one of infringement, $i . e$., tort, and had given no indication of willingness to make a contract, there was nothing from which a contract could be implied. Had the claim been based squarely upon constitutional rights, it is not unlikely that those rights would have been regarded as the vital point in the case, and the tort as subordinate, so that the doctrine of the Dooley case, simultaneously announced, might have covered the Russell case also.

The decision in the Dooley case was followed in Basso z. United States, ${ }^{17}$ where the facts enabled the court to draw a very clear distinction between the personal torts of Government officers, and torts which violate the constitutional or statutory rights of a private individual as against the Government. In 1899, while Porto Rico was still under a military government, the claimant was tried in the provisional court on the charge of having smuggled into the island certain articles of United States manufacture, and was sentenced to a fine of $\$ 1,500$ and one month's imprisonment. The decision in the Insular cases subsequently established the fact that Porto Rico was not a foreign country, and hence that, in the absence of legislation by Congress, articles manufactured in the United States were not sub- ject to any customs duty in the island, so that the claimant had not been guilty of any offense. His imprisonment was the personal tort of the officers who administered the government of Porto Rico, so that he had no recourse against the United States on account of it, but the imposition of the fine was a taking of his property, without authority of law, and for that taking he was entitled to recover, although it was also undoubtedly tortious. The Court of Claims said:

"Treating the judgment of the provisional court as void, as it must be, the fact results that the penalty of $\$ 1,500$ exacted was without legal warrant. No greater right existed to demand a penalty for the non-payment of a customs duty than for the pay-

1740 C. Cls. R., 202. 
ment of the duty itself. There was no authority of law to demand the one $\mathrm{cr}$ the other. The defendant received and still retains it. Is there any reason it should not be refunded to plaintiff? There is none in legal contemplation nor in good morals. . . .

It is suggested this court has no jurisdiction of the cause because the action is for damages sounding in tort. This same point was before the court and received its judgment in the Dooley case. . . .

Whether the present case be regarded as founded upon a law of Congress or upon a regulation of an Executive Department is immaterial, 35 the resilt is the same in either case, for according to the decision in the Dooley case both classes are put upon the same footing with respect to tortious characteristics and the jurisdiction of the court established. in that case the court analyzed the jurisdiction of this court as conferred by the Tucker Act in this manner:

"The first section evidently contemplates four distinct classes of cases: (I) Those founded upon the Constitution or any law of Congress, with an exception of pension cases; (2) cases founded upon a regulation of an Executive Department; (3) cases of contract, express or implied, with the Government; (4) actions for damages, liquidated or unliquidated, in cases not sounding in tort. The words 'not sounding in tort' are in terms referable only to the fourth class of cases."

The present case is not for damages, liquidated or unliquidated, and the question of whether the exaction of the penalty was tortious or not is not involved in the case.

It should not be the province of the court to hunt for doubts of jurisdiction in a case like this, where ail the demands of justice point to the right of plairtiff to be reimbursed the penalty unlawfully exacted. Judgment will be awarded against defendants for \$1,500."

The Dooley case has also been followed by the Circuit Court of Appeals for the Eighth Circuit in Christie-Strect Commission Co. v. United States, ${ }^{18}$ involving a clain for repayment of internal reventue taxes illegally collected. The opinion states that the Langford, Hill, Schillinger, and Lynah cases, above cited, "determine only whether the claims, upon which the actions there under consideration were based, were founded upon contracts with the Government, and fail to decide what claims are founded upon the laws of Congress." The opinion then cites the passage above quoted from Doolcy $v$. United States, and says:

18136 Fed., 326. 
"Nor does the argument persuade that the claim in the Dooley case was founded upon the Constitution because the duties collected were not uniform, as that instrument required them to be, while the claim at bar is not founded on the revenue law of 1898 , notwithstanding the fact that the taxes which the Government collected from the plaintiff were exacted by virtue of that law, and the misconstruction of it by its officers. In each case the United States exacted moneys without right, and in violation of the general rule that the property of the citizen may not be taken without legal authority. In each case the taking was tortious. In one case the claim was founded upon the Constitution and the war revenue law of 1898 . In the other it was founded upon that law alone. The Acts of 1855 and 1887 , however, vest in the courts as complete jurisdiction of a cause of action upon a claim founded upon a law of Congress as upon one founded upon the Constitution and the law."

It may therefore now be regarded as settled that in the case of claims "founded upon the Constitution of the United States, or any law of Congress, or upon any regulation of an Executive Department," the element of tort, even if present, does not prevent the court from taking jurisdiction. This doctrine is more just than that which prevailed before the passage of the Tucker Act, and even influenced the opinions (possibly the decisions also, in one or two instances) in cases brought under that Act. This doctrine has not yet been applied to suits on patents, but there is no reason why this should not be done; and its application would be much more logical, and much more certain in its effects, than the resort to the implication of contracts from facts which, at the time they oecurred, the parties concerned can hardly have regarded as contractual, and which, as between individuals, would never be relied upon as establishing a contract.

Charles C. Binney. 